\title{
SISTEM INFORMASI PENGOLAHAN DATA PENJUALAN PADA PABRIK ROTI GURIYANA BERBASIS NETBEANS
}

\author{
Ainyya Nur Affifah ${ }^{1}$, Siti Khotijah ${ }^{2}$, Ana Rusmardiana ${ }^{3}$ \\ ${ }^{1,2,3}$ Universitas Indraprasta PGRI \\ Jl. Raya Tengah No.80, RT.6 RW.1, Gedong, Kec.Pasar Rebo, Kota Jakarta Timur, 13760 \\ 1.
}

\begin{abstract}
ABSTRAK
Pabrik roti guriyana adalah pabrik roti yang belum memakai sistem informasi berbasis komputer dalam bagian pengolahan dalam penjualan, dimana masih menggunakan cara manual. Tujuan penelitian ini untuk membangun sistem pengolahan penjualan agar dapat dilakukan dengan lebih baik, cepat dan efisien serta dapat meminimalkan kesalahan yang ada sebelumnya. Metode yang digunakan untuk rancangan sistem ini adalah metode kualitatif dengan melakukan teknik wawancara dan observasi secara langsung dalam pengumpulan data yang dibutuhkan serta melakukan penelitian kepustakaan yang relevan. Model pengembangan sistem riset ini memakai tata cara waterfall pada SDLC serta bahasa pemrograman Java Netbeans dan Database MySQL. Dari penelitian ini menyimpulkan bahwa perlu adanya sistem pengolahan penjualan dalam pabrik roti yang lebih baik sehingga diharapkan penelitian ini dapat menghasilkan informasi yang lebih baik dengan sistem terkomputerisasi.
\end{abstract}

Kata Kunci: Sistem, Pengolahan Data, Penjualan, Netbeans, UML

\section{ABSTRACT}

Guriyana bread factory is a bread factory that has not used a computer-based information system in the processing section in sales, which still uses the manual method. The purpose of this research is to build a sales processing system so that it can be done better, faster and efficiently and can minimize errors that existed before. The method used for the design of this system is a qualitative method by conducting interviews and direct observation in collecting the required data and conducting relevant literature research. This research system development model uses the waterfall method in the SDLC and the Java Netbeans programming language and MySQL database. From this study concluded that there is a need for a better sales processing system in a bakery so that it is hoped that this research can produce better information with a computerized system.

Key Word: System, Data Processing, Sale, Netbeans, UML

\section{PENDAHULUAN}

Teknologi saat ini sangatlah diperlukan untuk suatu sistem informasi pengolahan data penjualan pada pabrik roti Guriyana di Kampung Dukuh. Sistem informasi tersebut berkaitan dalam setiap transaksi penjualan, pengisian data, sampai proses transaksi produk dan pembuatan laporan masih berupa arsip-arsip.

Pada pabrik roti Guriyana di Kampung Dukuh adalah pabrik roti yang belum memakai sistem informasi berbasis komputer dalam bagian olah pada data penjualan, dimana sistem proses datanya saat ini masih bersifat manual. Proses olah pada data penjualan masih dilakukan secara sederhana dengan menggunakan kertas yang harus dicatat sehingga proses tersebut dapat menyita waktu, penyimpanan data masih berupa arsip dan sering terjadi permasalahan seperti transaksi penjualan, kasir melakukan pencatatan data produk keluar sehingga menghabiskan banyak kertas, perhitungan penjualan kurang akurat, dan membuat laporan membutuhkan waktu yang sangat lama.

Adapun tujuan penelitian adalah untuk mengetahui sistem informasi pengolahan data penjualan yang sedang berjalan pada pabrik roti Guriyana di Kampung Dukuh sebagai bahan pertimbangan dalam melakukan pengembangan sistem yang akan dilakukan. Untuk mengembangkan sistem pengolahan data penjualan pada pabrik roti Guriyana di Kampung Dukuh yang sedang berjalan ke dalam bahasa pemrograman java dengan menggunakan database MySQL. Dan Membuat sistem penjualan yang dapat mempermudah dalam mengelola data yang terdapat di pabrik roti Guriyana di Kampung Dukuh. Serta Menganalisa pengolahan pada 
penjualan yang lebih efektif dengan menggunakan komputer.

Manfaat bagi Pabrik Roti Guriyana di Kampung Dukuh adalah meningkatkan sistem pengelolaan data penjualan. Transaksi lebih efektif sehingga dapat meningkatkan efisiensi waktu kerja. Dan mengatasi kesulitan dalam pengelolaan data penjualan.

Menurut Mulyadi (2016:4) "Sistem adalah jaringan dalam prosedur yang dirancang dengan rangkaian yang terpadu". Menurut Tata Sutabri (2012:22) "Informasi merupakan data yang sudah nyata kebenarannya diolah atau diinterpretasikan".

Menurut Hutahaean (2014:8) "Pengolahan data merupakan operasi terhadap informasi yang sudah dirancang untuk hasil yang diinginkan". Menurut Mulyadi (2016:39) "Penjualan merupakan suatu fungsi yang dianggap sebagai ujung tombak dalam suatu perusahaan karena fungsi itulah perusahaan memperoleh pendapatan,

Basis data adalah koleksi dari data-data yang terorganisasi cara sedemikian rupa sehingga data mudah disimpan dan dimanipulasi (diperbaharui, dicari, diolah dengan perhitungan-perhitungan tertentu serta dihapus). Menurut Nofriadi (2015:4) "Netbeans merupakan aplikasi Integrated Development Environment (IDE) yang berbasis Java Netbeans".

Menurut Gata (2013:59) "Unified Modelling Language (UML) ialah bahasa spesifikasi standar yang digunakan untuk mendokumentasikan dan membangun software". Menurut Uus Rusmawan (2019:64) "Diagram hubungan entitas atau entity relationship diagram merupakan model data berupa notasi grafis di dalam pemodelan data konseptual yang menggambarkan hubungan antara penyimpan. Menurut Nugroho (2011:33) "Normalisasi adalah tahapan yang masing-masing berhubungan dengan bentuk normal."

\section{METODE PENELITIAN}

\section{Desain Penelitian}

Melalui tahapan struktur data lalu arsitektur piranti lunak sehingga mendapatkan gambaran detil prosedur dalam membuat desain pada penelitian dan nilai antarmuka pemakai perlu diketahui agar tahapan untuk mendesain aplikasi dapat maksimal menjadi lebih baik.

Bahan dapat digunakan untuk penelitian ini, yaitu:

\section{Hardware}

Perangkat keras untuk penelitian yaitu perangkat keras Personal Computer dengan spesifikasi AMD A4-3330MX APU with Radeon(tm) HD Graphics, berkecepatan hingga 2,30 GHz, RAM 2.00 GB, Keyboard, Mouse, Printer.

\section{Software}

Perangkat lunak berguna untuk sistem operasi dalam penelitian yaitu Operating System Microsoft Windows 7 Ultimate, Microsoft Visio sebagai tool membuat desain rancangan, Netbeans 8.2 sebagai desain aplikasi dan program, serta $M y S Q L$ digunakan sebagai basis data.

\section{Metode Pengumpulan Data}

Pengumpulan data tidak lain dari suatu proses pengadaan data untuk keperluan penelitian. Cara dalam pengumpulan data dilakukan oleh penulis agar mendapatkan data dan informasi dalam menyempurnakan hasil dari penelitian ini antara lain:

\section{Studi Kepustakaan (Library Research)}

Pengumpulan data dan informasi dilakukan dengan cara mencari buku yang berhubungan dengan masalah yang dibahas diperoleh dari perpustakaan Kampus. Pengumpulan data dan informasi dilakukan dengan meminjam buku di perpustakaan Universitas Indraprasta PGRI, untuk melakukan studi kepustakaan ini penulis berusaha mencari referensi teori-teori dengan browsing melalui search di internet.

\section{Studi Lapangan (Field Research)}

Penulis melakukan studi lapangan dengan cara peninjauan secara langsung agar memperoleh data-data yang diperlukan dalam penyusunan tugas akhir. Metode penelitian dilakukan dengan beberapa hal dibawah ini:

\section{a. Observasi}

Observasi dilakukan dengan cara melihat dan mencatat data yang ada yang diperlukan untuk penelitian. Dan meminta berkas-berkas data penjualan 
roti pada Pabrik Roti Guriyana yang proses berjalan.

b. Metode Wawancara

Dengan melakukan pertanyaan langsung pada pihak-pihak atau orang orang yang memiliki hubungan atau mengetahui sistem penjualan roti pada Pabrik Roti Guriyana dalam hal pemilik atau karyawan.

\section{Langkah-Langkah Pengembangan Sistem}

Aplikasi dalam penerapan dari penemuan masalahan yang didapat dar pendekatan sistem dalam pengembangan dan masukan solusi sistem informasi dalam masalah bisnis. Dalam pengembangan sistem, penulis menggunakan metode waterfall.. Pada proses waterfall ditunjukkan metode pengembangan dimana pengembang aplikasi diharuskan mengikuti langkah-langkah sebagai berikut:

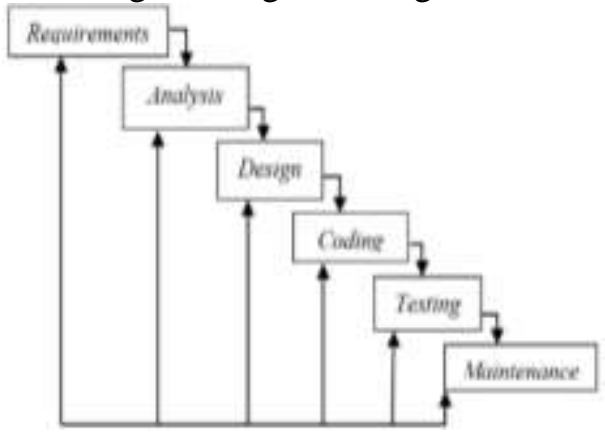

Gambar 1. Pemodelan Waterfall pada SDLC

Menurut Irwansyah (2012:16), penjelasan dari tahap-tahap waterfall model adalah sebagai berikut:

\section{Perancangan Sistem (System} Enginering)

Pembuatan sebuah piranti lunak dapat dimulai dengan melihat dan mencari apa yang dibutuhkan oleh sistem. Dari kebutuhan sistem tersebut akan diterapkan kedalam piranti lunak yang dibuat.

2. Analisa Kebutuhan Piranti Lunak (Software Requirement Analysis)

Seorang analisis diutamakan dapat mengerti ruang lingkup informasi, fungsifungsi yang dibutuhkan, kemampuan kinerja yang ingin dicapai dan perancangan antarmuka pemakai piranti lunak tersebut.

3. Perancangan (Design)

Pengembangan perlahan yang difokuskan dalam empat bagian penting, yaitu: struktur data, arsitektur piranti lunak, detil prosedur, dan karakteristik antarmuka pemakai.

\section{Pengkodean (Coding)}

Proses penulisan bahasa program agar piranti lunak tersebut dapat dijalankan oleh mesin.

\section{Pengujian (Testing)}

Proses ini akan menguji kode program yang telah dibuat dengan memfokuskan pada bagian dalam piranti lunak. Tujuannya untuk memastikan bahwa semua pernyataan telah diuji dan memastikan juga bahwa input yang digunakan akan menghasilkan output yang sesuai.

\section{Pemeliharaan (Maintenance)}

Proses ini dilakukan setelah piranti lunak telah digunakan oleh pemakai atau konsumen. Perubahan akan dilakukan jika terdapat kesalahan, perubahan kebutuhan yang diinginkan konsumen.

\section{HASIL DAN PEMBAHASAN}

Admin dapat mengakses input data dan cetak laporan

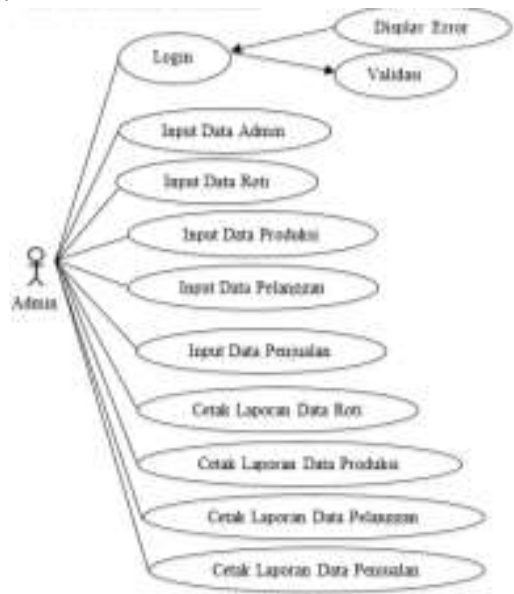

Gambar 2. Use Case Sistem Diusulkan

Gambar dibawah ini menjelaskan proses penggunaan sistem pada saat Admin memilih icon aplikasi:

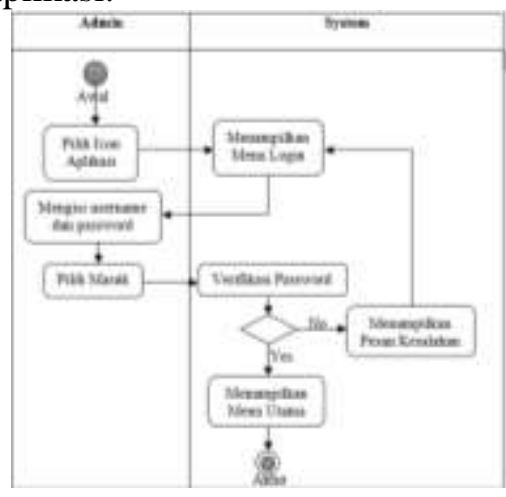

Gambar 3. Activity Diagram Login 
Gambar dibawah ini menjelaskan proses penggunaan sistem pada saat Admin memilih menu data admin:

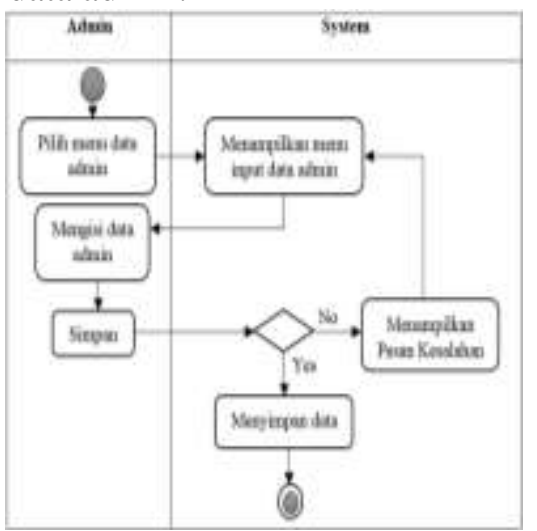

Gambar 4. Activity Diagram Input Data Admin

Gambar dibawah ini menjelaskan proses penggunaan sistem pada saat Admin memilih menu input data roti:

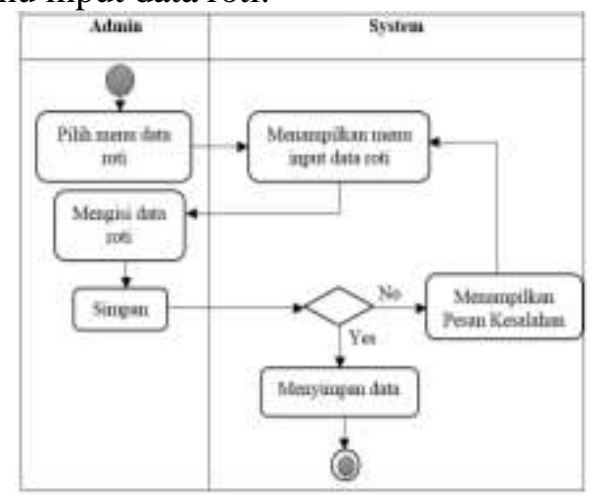

Gambar 5. Activity Diagram Input Data Roti

Gambar dibawah ini menjelaskan proses penggunaan sistem pada saat Admin memilih menu input data produksi:

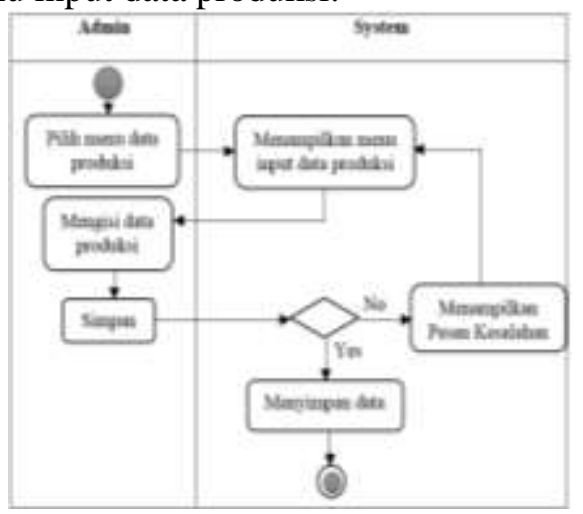

Gambar 6. Activity Diagram Input Data Produksi

Gambar dibawah ini menjelaskan proses penggunaan sistem pada saat Admin memilih menu input data pelanggan:

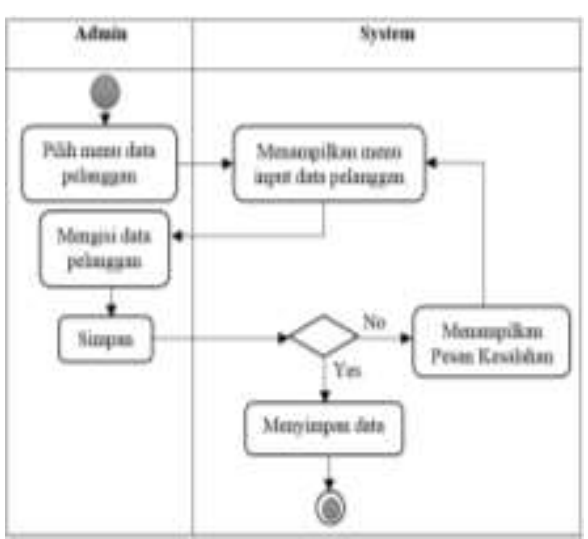

Gambar 7. Activity Diagram Input Data Pelanggan

Gambar dibawah ini menjelaskan proses penggunaan sistem pada saat Admin memilih menu input data penjualan:

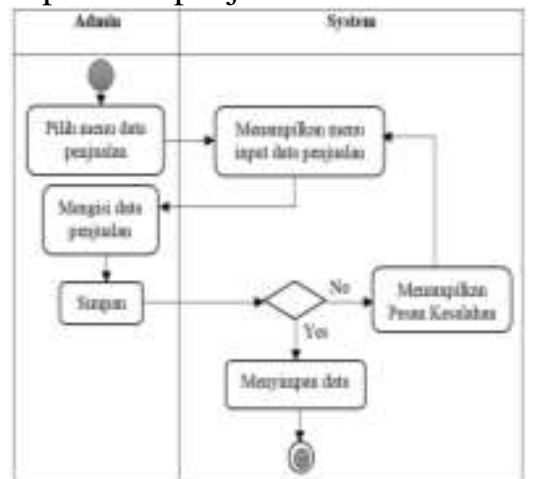

Gambar 8. Activity Diagram Input Data Penjualan

Sequence diagram login menggambarkan pandangan sederhana tentang bagaimana proses login pada sistem.

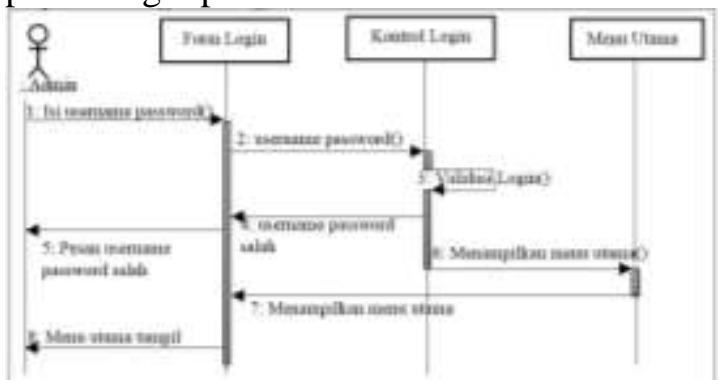

Gambar 9. Sequence Diagram Login

Sequence diagram input data admin menggambarkan pandangan sederhana tentang bagaimana proses admin menginput data sehingga data dapat tersimpan disistem.

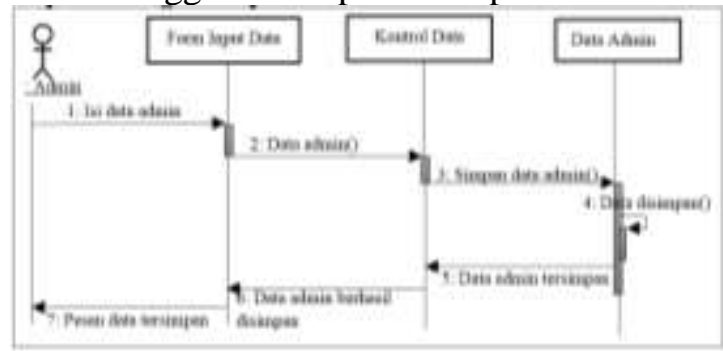

Gambar 10. Sequence Diagram Input Data Admin 
Sequence diagram input data roti menggambarkan pandangan sederhana tentang bagaimana proses admin menginput data sehingga data dapat tersimpan disistem.

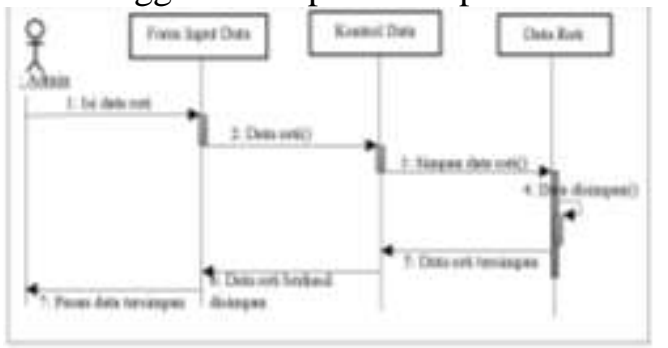

Gambar 11. Sequence Diagram Input Data Roti

Sequence diagram input data produksi menggambarkan pandangan sederhana tentang bagaimana proses admin menginput data sehingga data dapat tersimpan disistem.

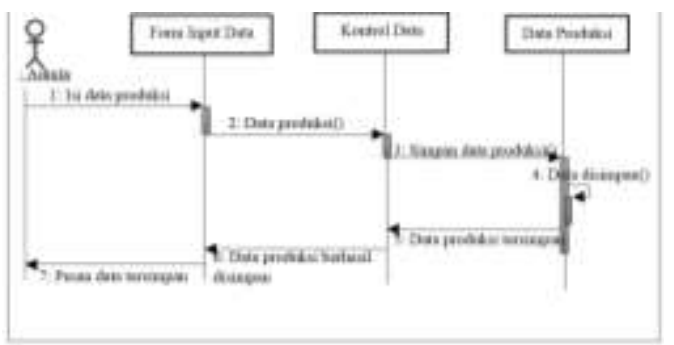

Gambar 12. Sequence Diagram Input Data Produksi

Sequence diagram input data pelanggan menggambarkan pandangan sederhana tentang bagaimana proses admin menginput data sehingga data dapat tersimpan disistem.

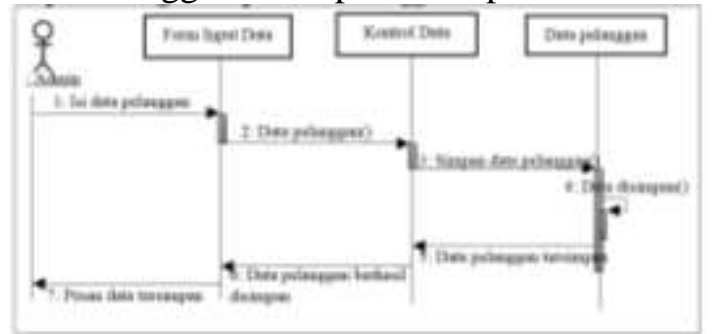

Gambar 13. Sequence Diagram Input Data Pelanggan

Sequence diagram input data penjualan menggambarkan pandangan sederhana tentang bagaimana proses admin menginput data sehingga data dapat tersimpan disistem.

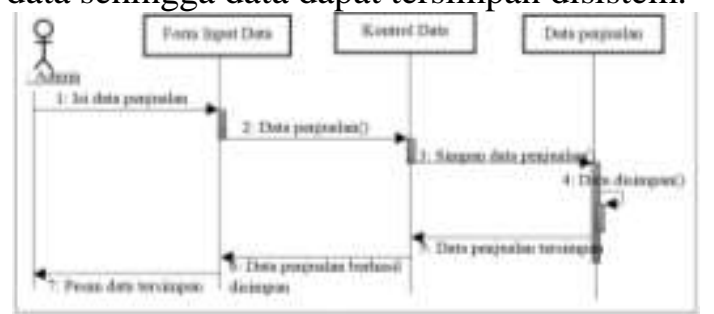

Gambar 14. Sequence Diagram Input Data Penjualan
Class Diagram menggambarkan struktur dari setiap segi pendefinisian kelas yang digunakan untuk membangun sistem.

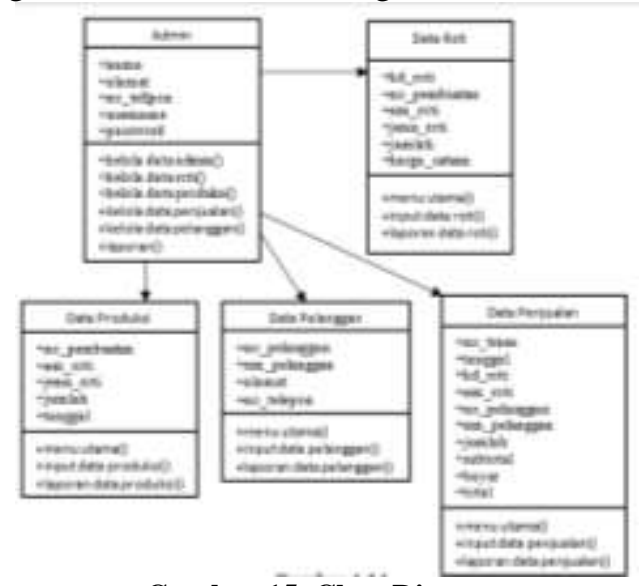

\section{Gambar 15. Class Diagram}

Tabel Unnormal menjelaskan atribut-atribut yang digunakan pada sistem tidak normal karena adanya kesalahan nama atribut.

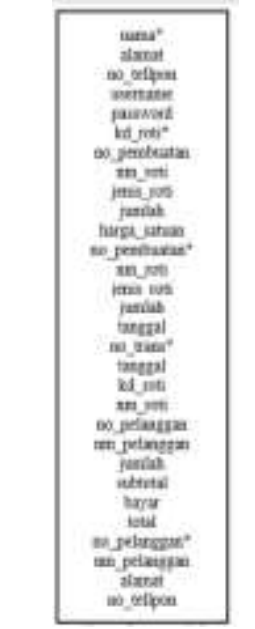

Gambar 16. Unnormal

Tabel normal menjelaskan atribut-atribut dibawah saat digunakan pada sistem normal dan benar.

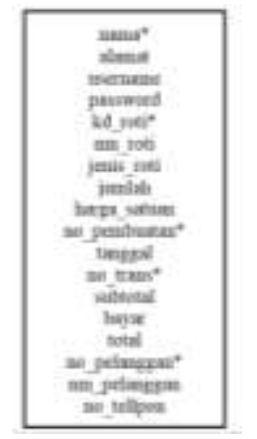

Gambar 17. Normal

Tabel normal menjelaskan atribut-atribut dibawah saat digunakan pada sistem normal dan benar. 


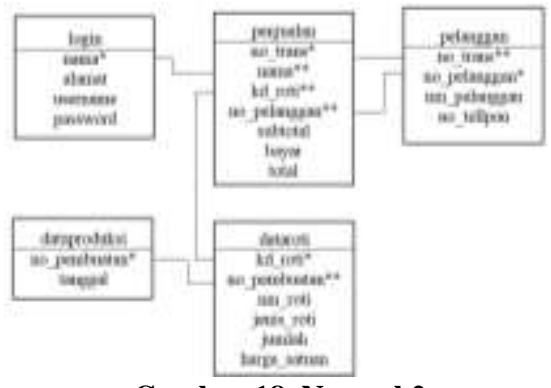

Gambar 18. Normal 2

Tabel normal menjelaskan atribut-atribut dibawah saat digunakan pada sistem normal dan benar.

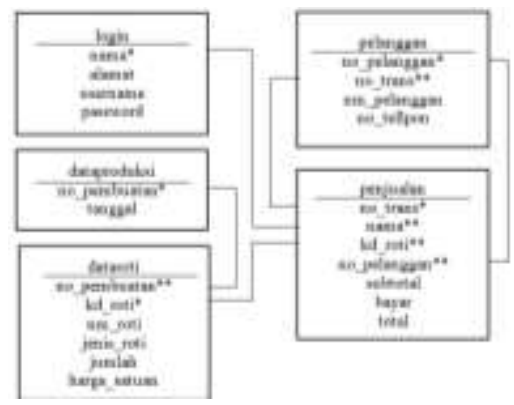

Gambar 19. Normal 3

Diagram ERD menggambarkan databasedatabase yang saling berelasi pada sistem

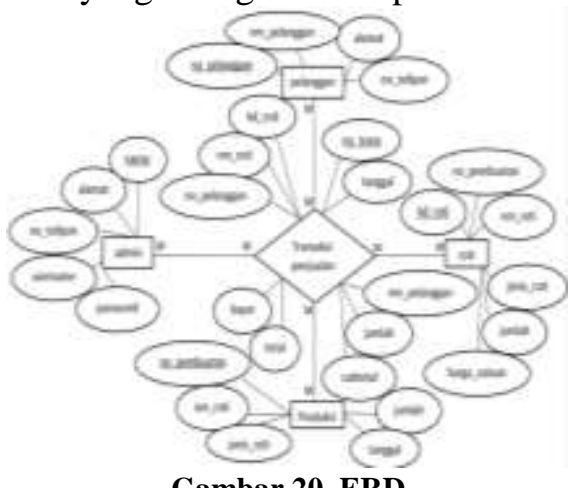

Gambar 20. ERD

Gambar dibawah ini adalah tampilan pada form login:

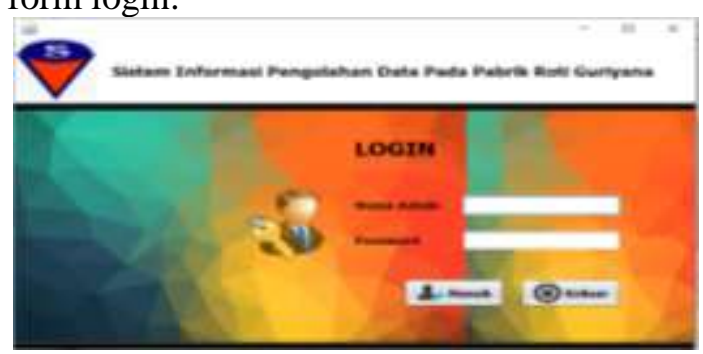

Gambar 21. Tampilan Form Login

Gambar dibawah ini adalah tampilan pada form menu utama:

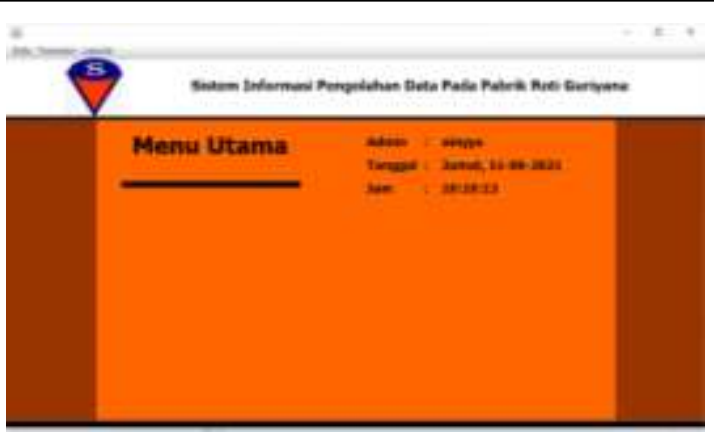

Gambar 22.Tampilan Form Menu Utama

Gambar dibawah ini adalah tampilan pada form Admin:

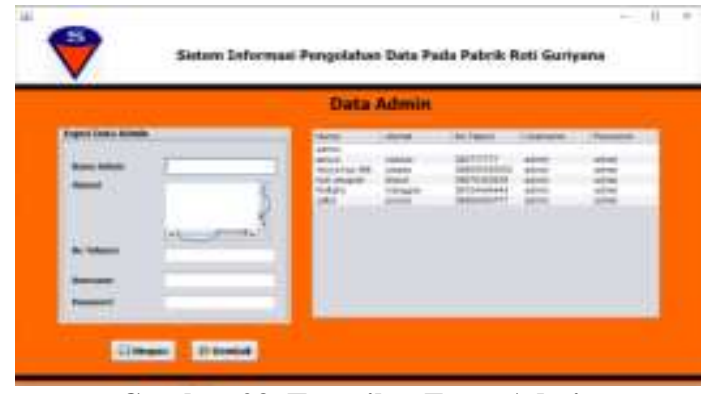

Gambar 23. Tampilan Form Admin

Gambar dibawah ini adalah tampilan pada form roti:

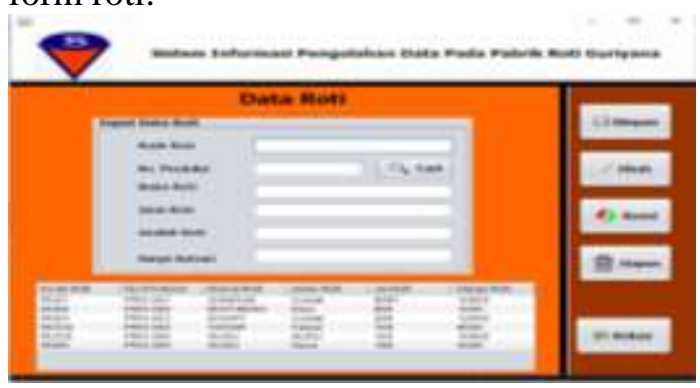

Gambar 24. Tampilan Form Data Roti

Gambar dibawah ini adalah tampilan pada form data produksi:

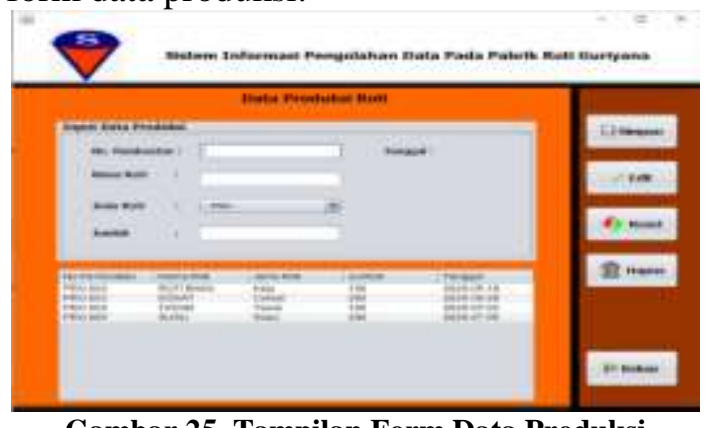

Gambar 25. Tampilan Form Data Produksi

Gambar dibawah ini adalah tampilan pada form data penjualan: 


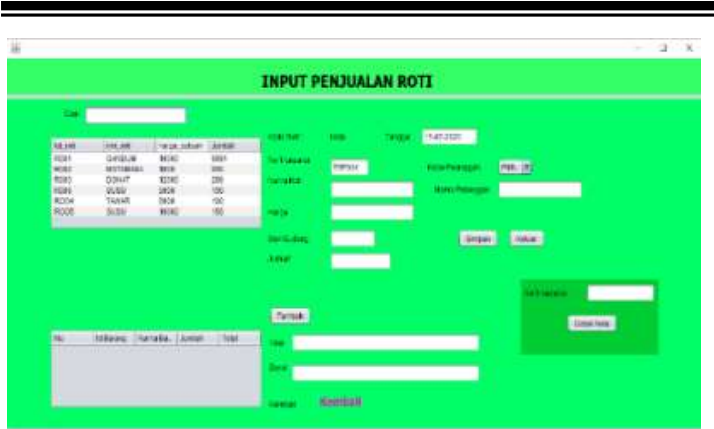

Gambar 26. Tampilan Form Data Penjualan

Gambar dibawah ini adalah tampilan pada form data pelanggan:

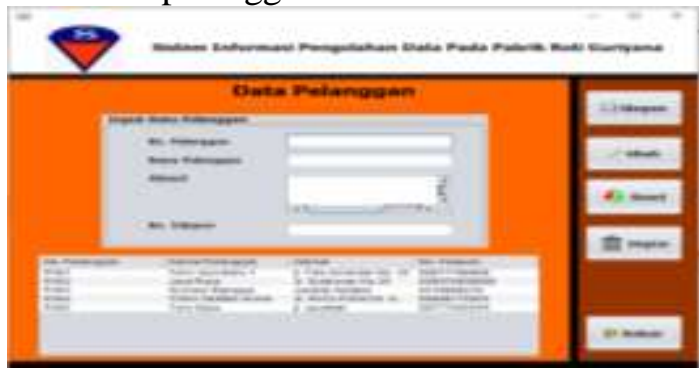

Gambar 27. Tampilan Form Data Pelanggan

Gambar dibawah ini adalah tampilan pada form laporan data roti:

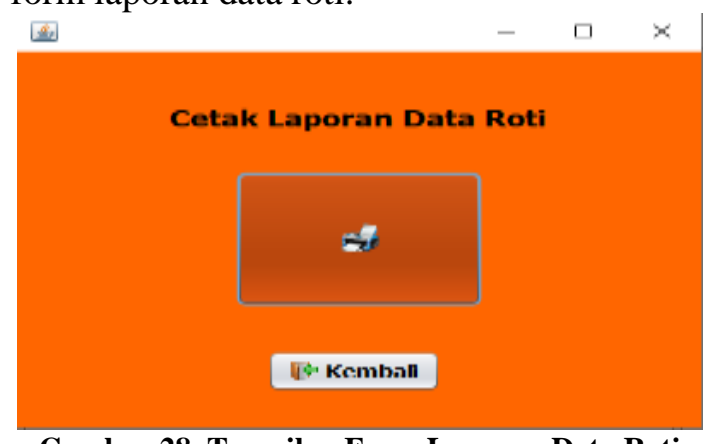

Gambar 28. Tampilan Form Laporan Data Roti

Gambar dibawah ini adalah tampilan form bukti laporan data roti:

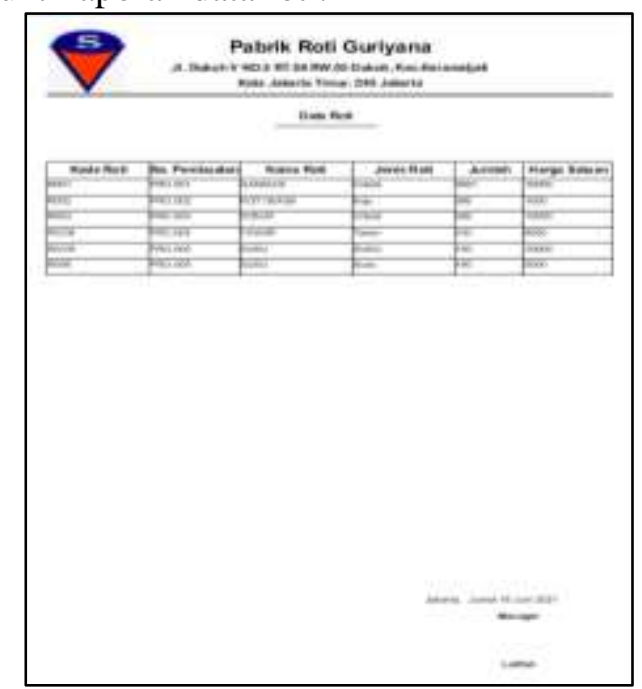

Gambar 29. Tampilan Form Bukti Laporan Data Roti
Gambar dibawah ini adalah tampilan pada form laporan data produksi:

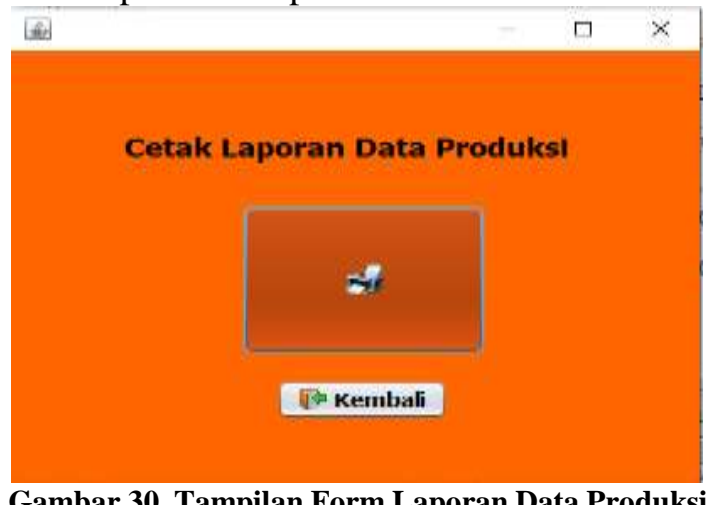

Gambar dibawah ini adalah tampilan pada form bukti laporan data produksi:

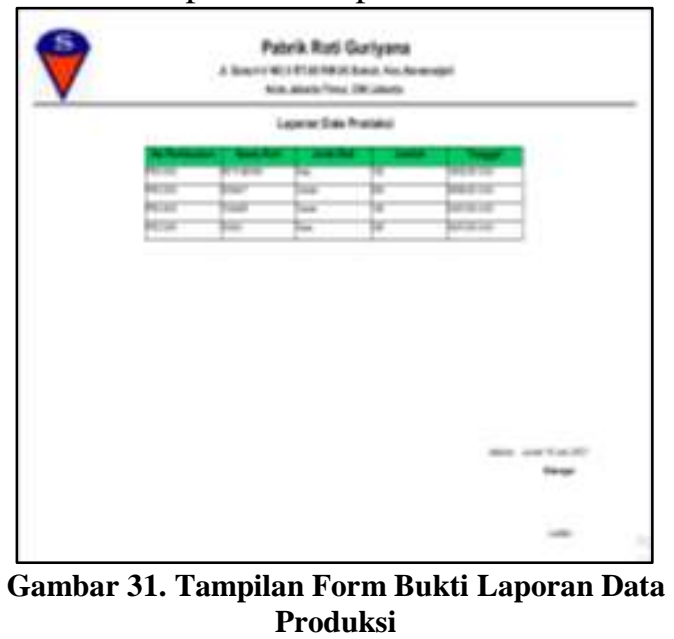

Gambar dibawah ini adalah tampilan pada form laporan data penjualan:

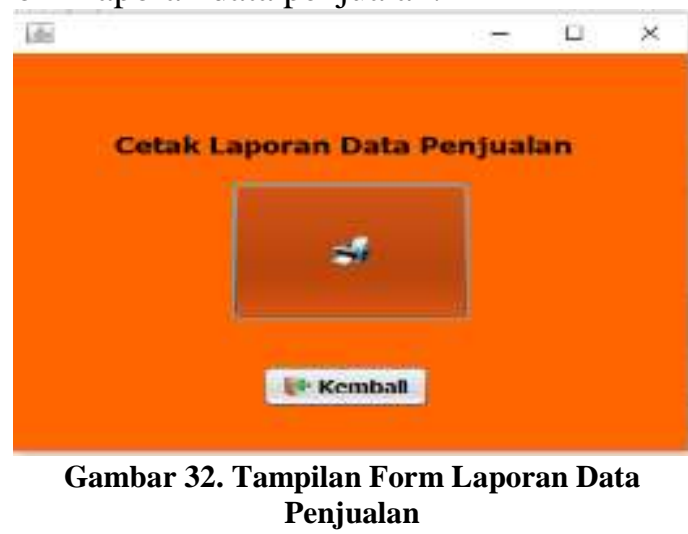

Gambar dibawah ini adalah tampilan pada form bukti laporan data penjualan: 


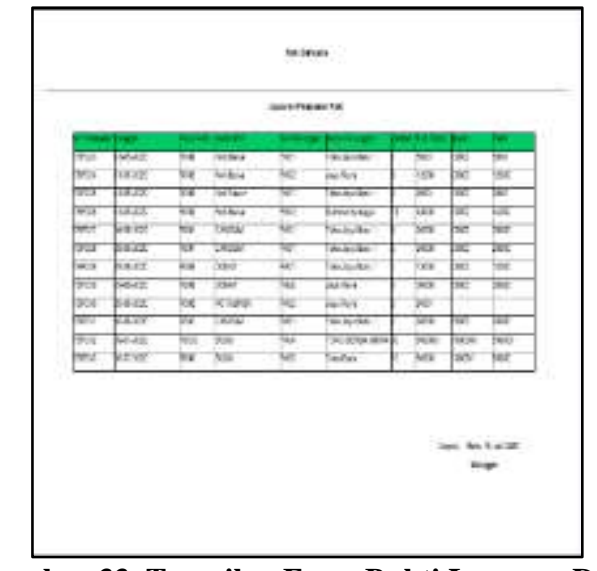

Gambar 33. Tampilan Form Bukti Laporan Data Penjualan

Gambar dibawah ini adalah tampilan pada form laporan data pelanggan:

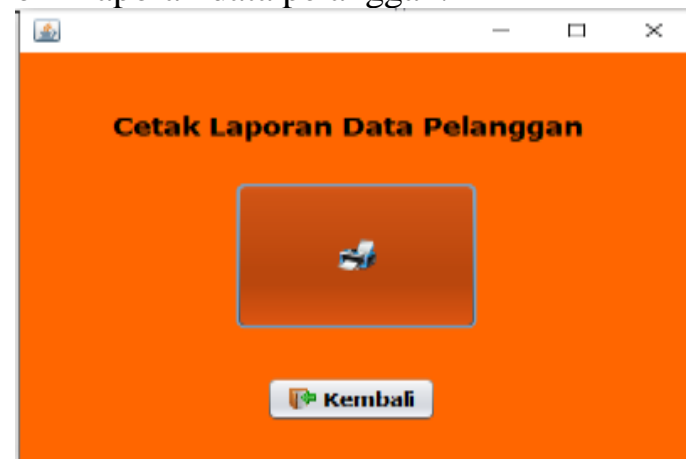

Gambar 34. Tampilan Form Laporan Data Pelanggan

Gambar dibawah ini adalah tampilan pada form bukti data pelanggan:

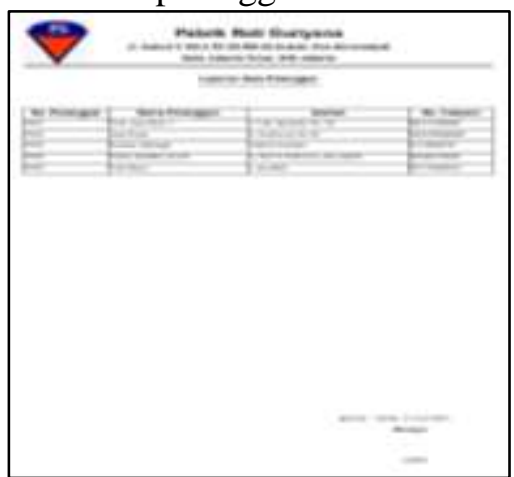

Gambar 35. Tampilan Form Bukti Data Pelanggan

\section{SIMPULAN DAN SARAN}

Dengan dibuatnya Sistem Informasi Pengolahan Data Penjualan Pada Pabrik Roti Guriyana, semua kegiatan berhubungan dengan penjualan menggunakan Netbeans. Dengan adanya perangkat komputer sebagai alat bantu, dalam penulisan ini dapat diambil simpulan sebagai berikut :

Perancangan sistem dibuat dengan cara membuat program memakai aplikasi netbeans untuk mempermudah dalam mendata, mengolah, dan menyimpan data agar lebih aman, cepat dan efisien. Perancangan Sistem menggunakan memakai bahasa pemrograman java.

Pelayanan dalam Sistem dengan cara menginput data admin, data roti, data produksi, data transaksi penjualan dan data pelanggan dalam aplikasi ini sehingga mempermudah bagian admin dalam mengolah data tersebut. Data yang diolah dan diproses oleh sistem akan disimpan kedalam database pada penyimpanan internal komputer,

Sejalan dengan sistem usulan yang penulis buat, maka demi tercapainya tujuan dan sasaran yang diharapkan, maka penulis dapat memberi saran sebagai berikut: Sistem Pengolahan Data Penjualan dapat dikembangkan kembali dalam hal design atau penambahan database. Sistem Pengolahan Data Penjualan haruslah didukung oleh sistem yang disiplin dan peraturan yang baik.Uji coba terhadap Pengolahan Data Penjualan Pada Pabrik Roti Guriyana kepada bagian admin dapat segera dipercepat proses pelatihan agar Sistem dapat digunakan secepatnya oleh admin Pabrik Roti Guriyana.

\section{DAFTAR PUSTAKA}

Mulyadi.(2016). Sistem Informasi Akuntansi. Jakarta: Salemba Empat.

Sutabri, Tata.(2012). Konsep Sistem Informasi. Andi: Yogyakarta.

Hutahaean,Jeperson.(2014).Konsep Sistem Informasi. Yogyakarta: Deepublish.

Sutarman. (2012). Pengantar Teknologi Informasi. Bumi Aksara: Jakarta.

Nofriadi. (2015). Java Fundamental denganNetbeans 8.0.2. Yogyakarta: CV Andi Offset.

Gata, W. G. dan G.(2013). Sukses Membangun Aplikasi Penjualan Dengan Java. Jakarta: PT Elek Media Komputindo

Rusmawan, Uus.(2019). Buku Teknik Penulisan Tugas Akhir dan Skripsi Pemrograman. Jakarta: Penerbit PT Elex Media Komputindo,

Nugroho, Bunafit.(2013). Dasar Pemograman Web PHP - MySQL dengan Dreamweaver. Gava Media: Yogyakarta. 